\title{
Learners' Perspectives of their Learning Styles: A Case Study in Alice, Fort Beaufort District in the Eastern Cape Province
}

\author{
Ntombekhaya Caga
}

\author{
Faculty of Education, School of Further and Continuing Education, University of Fort Hare \\ npcaga@ufh.ac.za
}

\section{Doi:10.5901/mjss.2014.v5n27p620}

\begin{abstract}
The aim of this study was to investigate the preferred learning styles of 110 Grade 8 English first additional language learners in Alice, Fort Beaufort district in the Eastern Cape Province. The study sought to identify learners' preferred learning styles in order to get learners to know learning styles that suit themselves, yet in an indirect manner to consider learning alternatives. By doing so, they would be able to acquire the knowledge and skills they need to become more proficient in English first additional language. Quantitative data were collected from 110 Grade 8 English first additional language learners from two senior secondary schools in Alice, Fort Beaufort district using classroom work style survey to identify the most and least preferred learning styles used by individual learners. Quantitative data were analysed by categorizing them into learning style preferences and presented in tables shown in the findings. Research findings showed that the most prevalent learning style for learners was the visual learning style. This study, therefore, recommends that English first additional language learners should know their learning styles in order to determine their own personal strengths and weaknesses that would help them to be more proficient in English first additional language.
\end{abstract}

Keywords: Eastern Cape Province, first additional language, learning style

\section{Introduction}

The South African political change that started in the early 1990s, and culminated in the 1994 election of a democratic government, put great demands on educational reform. The mission of change, was evident in educational implementation policies, which also encompass the acknowledgement of human diversity. One of the principles on which CAPS (2011) for Grade 8 English first additional language was based, was the sensitivity to issues of diversity, such as, learning styles, among others. The document further states that inclusivity should become a central part of the organisation, planning, and teaching at each school. This can only happen, if all teachers have a sound understanding of how to recognise and address barriers to learning, and how to plan for diversity. It means that, during English first additional language teaching, learners' differences, including learning styles, must be accommodated, so that learners can all achieve their full potential at different levels, according to their preferred learning styles. There are various definitions of learning styles as there are authors. Learning styles are manners in which individuals perceive and process information in the learning process. According to Ellis (2010) learning style refers to the characteristic ways in which individuals orientate to problem-solving. According to Brown (2000) learning style preference refers to the choice of one learning situation or condition over another.

Everyone has a mix of learning styles. Some people may find that they have a dominant style of learning with far less use of the other styles. Others tend to use different styles in different circumstances. By recognising, and understanding, learners' learning styles, teachers could use teaching techniques better-suited to the learners. This requires that there be a deliberate and concerted effort to identify learners' learning styles, in order to cater for them, when selecting teaching styles for their lessons. The intended outcome is to make it possible for learners to use English with minimal difficulties. In this paper, the focus is on how learners perceive information using their senses, known as perceptual learning styles. According to Sprenger (2002) a perceptual learning style indicates that learners absorb new material and skills through their senses, and prefer some senses to others in specific situations. A perceptual learning style is also referred to as a sensory learning style. There are five styles in this category; namely, visual learners; auditory learners; verbal or linguistic (reading or writing) learners; tactile learners; and kinaesthetic learners. The other two senses, smells and tastes, are usually lumped in with the kinaesthetic sense, since they involve an action (Flemming, 2001).

(i) Visual-oriented learners learn by seeing. They prefer a visual representation of the information. According to 
Ellis (2010) a visual-oriented learner likes reading and studying charts. They enjoy seeing words, or looking at teaching materials. They prefer to look at what is written on the writing board to listening to what the teacher is saying. This implies that lectures, conversations, or oral directions, without any visual backup, are very confusing, and could be anxiety-producing. Writing information gives visual learners the opportunity to see how concepts fit together. They take copies, notes, even if they won't need to look at them a second time. They learn best through group work, and feedback from their peers.

(ii) The auditory preference learners usually prefer to learn by listening and speaking. According to Ellis (2010) they are comfortable with lectures, and listening to audio tapes. They master new information by listening, then repeating, or discussing it with others. Meltzoff (2000) suggests that teachers must use various ways of transferring information, because these learners need to talk as much as they need to listen. They have strong language skills. Their vocabularies are frequently extensive. They enjoy words, and speak in a rhythmical fashion (Sprenger, 2003). Spelling is done by sounding words out, and their spelling is often wrong, as a result; they do not like to write much. What makes learning real to them is being able to talk about things. Working on group or team projects gives these learners the opportunity to talk through the material. They feel frustrated when teachers write assignment and test instructions on the writing board, or on a handout, but not deal with it orally.

(iii) Learners with verbal or linguistic intelligence learn by processing text. This involves all forms of working with language, including the ability to read the newspaper, a novel, or labels on various products we buy. It gives learners the ability to write essays, poetry, reports, and letters, to conduct formal speaking before an audience. It also involves informal conversation with a friend, and it involves listening to the words of other persons, and being able to understand what they are saying, and intend to communicate.

(iv) Tactile learners prefer to learn by feeling, or touching something with their hands. The tactile preference includes different types of learners, such as hands-on learners, doodlers, etc. Hands-on learners like to manipulate materials that are touchable and moveable. Doodlers learn through drawings, colouring, and doodling at their desks while a discussion is going on. Sprenger (2003) says that they need to do something, in order to learn it. These learners usually process the information best through assembling, taking things apart, working with textured materials, and manipulating objects.

(v) Kinaesthetic learners like movement. Bodily kinaesthetic learners need to become what they are learning. Ellis (2010) argues that these learners like to involve physical responses during second language learning. This may include role-playing, exercising, building, giving live demonstrations, and using whole-body movements. There are learners who possess more than one learning style. They are called compound learning style learners. According to Winkler (2007) learners who understand their learning styles, can work to make the best of both their own individual differences, as well as teaching styles that do not necessarily provide the environment in which they learn best.

There are numerous studies on learners' learning styles identification, however, there are relatively few research conducted in South Africa specifically on how an understanding of learners learning styles could help learners learning the English first additional language, therefore, publications are limited. Authors that have conducted research on learning styles are: Peacock (2001); Zhenhui (2001). Funderstanding (2008); Aguirre, Cancino and Neira (2005) Guadalupe, Castaneda and Juris (2007); Felder, Felder and Diet (2002); Gilbert and Swanier (2008). The findings of the study conducted by Guadalupe, Castaneda, Juris (2007) showed that tactile, auditory, kinaesthetic learning styles were dominating. Funderstanding (2008) revealed that learning styles are reflected in learners' academic strengths, weaknesses, skills and interests.

\section{Theoretical Framework}

This study was entirely based on constructivist orientation to learning which posits that learning is an active and constructive process in which the learner actively constructs his or her own understandings of reality through interaction with objects, events, and people in the environment, and reflecting on these interactions (Learning Theories 2008). The National Curriculum Statement (NCS), as implemented in South African schools, follows a constructivist approach to learning which views learners as active participants who have much to contribute to the teaching-learning process (Department of Education, 2011). It promotes interactive and learner-centred teaching approaches to produce multiskilled, literate and independent learners (Department of Education, 2002; Gibbons, 2002; Hawkins, 2000; 1988). To ensure active participation and construction of knowledge for all learners, addressing learners' individual learning styles seems to be important. In supporting the latter, Howard Gardner(1983) s' theory of multiple intelligences has been 
chosen because it describes the perceptual learning styles of learners, elaborating and distinguishing between preferences in these learning styles. The core idea of Gardners' theory is that teachers should teach learners according to their preferences .

According to Gardner (1983) every person has his or her own preferred learning style, working style and temperament. He sees learning style as a combination of among other things, how we perceive information most easily. whether a person is mainly visual, auditory, kinaesthetic or tactile learner. That means whether a person learns best by seeing, hearing, moving or touching.

\section{Statement of the Problem}

The Language in Education Policy (LIEP) of 1997 sought to ascertain that learners learn two languages, one being the mother tongue, with the other one being an additional language. The researcher often visit schools in Fort Beaufort district during student teaching practice, which is one of the modules towards the attainment of both the Bachelor of Education (B-Ed) degree, and Postgraduate Certificate in Education (PGCE). She noticed that the Grade 8 English first additional language learners in selected schools were unable to communicate confidently and effectively in English. This was evident when most of the utterances produced were ill-formed according to the rules of the standard English language. It is believed that learners who understand their learning styles, can work to make the best of both their own individual differences, as well as teaching styles that do not necessarily provide the environment in which they learn best. The learners' learning styles should first be identified, hence the research question is

$>$ What are the most preferred learning styles of Grade 8 English first additional language learners in selected schools in Alice, Fort Beauford District?

\section{Research Methodology}

The quantitative case study was used in this study. Yin (2009) defines the case study research method as an empirical inquiry that investigates a contemporary phenomenon within its real-life context; when the boundaries between phenomenon and context are not clearly evident; and in which multiple sources of evidence are used. a Case study was most suitable when the researcher desired to understand complex social phenomena, such as classroom interaction within a real-life context, and is interested in answering 'how' and 'why' questions, i.e., how do learners learn, and why? The researcher chose to investigate Grade 8 learners, in this case. Quantitative research essentially refers to the application of the systematic steps of the scientific method, while utilising quantitative properties (i.e., numerical systems) to research the relationships or effects of specific variables (Edmonds \&Kennedy, 2013). Purposive sampling was used. In purposive sampling, a particular case is chosen, because it illustrates some feature, or process, that is of interest for a particular study. Grade 8 learners in selected schools were chosen for convenience, being the location of the closest secondary schools, in terms of where the researcher is located. Secondly, both Grade 8 English classes consisted of learners whose mother tongue is IsiXhosa. It was their first year at senior secondary school, and they came from different primary schools. According to Babbie (2005:112), the researcher must decide who or what to study. The population for a study is that group (usually of people) about whom one wishes to draw conclusions. The target population consist of 110 Grade 8 English first additional language learners at the two selected senior secondary schools in Alice, Fort Beaufort District.

\section{Data Collection Instruments}

Quantitative data were collected from learners using classroom work style survey in both schools to identify the most and least preferred learning styles used by individual learners. This survey was done in a non-western context, meaning using the written exercise, instead of using computers, because, in both schools, learners had no access to technology. Learners were asked to fill in Kinsella (1995) classroom work style survey, to gain a better understanding of the way each learner preferred to learn, or process information. Although English is the language of learning and teaching in both schools, most of the learners had limited reading proficiency in it. The survey was administered in English and IsiXhosa in both schools. The researcher translated the English version of some statements into IsiXhosa to assist some of the learners to understand the meaning of the terms in their first language. She explained to learners in both schools how to complete the survey. The class work style survey was composed of two parts which were divided into tables. Each table consisted of statements and a list of answers. In table 1, seven statements were written with three answers to choose from, except for statements five and seven which had two answers each. Learners were asked to tick the box opposite to 
one that she or he thinks matches the statement that explains himself. It was intriguing to say the least, that some of the learners needed to resort to IsiXhosa to be able to write their responses, and they were comfortable when writing using the IsiXhosa version. The results were then analysed by categorising them into according to the aforementioned learning style preferences and presented in tables shown in the findings.

\section{Ethical Issues}

Confidentiality is designed to protect the privacy of the individual and protect that individual from harm (Shank, 2006). The researcher adhered to ethics of confidentiality and anonymity, and the right to privacy, as alluded to by Anderson (2002). According to Cohen, Manion, and Morrison (2000) the essence of anonymity is that information provided by research participants should, in no way, reveal their identities. Codes were used to protect these identities. The researcher asked permission to conduct research in the two selected schools in Alice from the school principals. The principals undertook to inform the District Office of the research, and gave the researcher permission in writing to visit the Grade 8 English classrooms. The parents, or guardians, of the learners were also asked to sign consent forms, giving their informed consent, on behalf of their children. The respondents were informed that all the information collected would be treated in strict confidence, and used only for research purposes.

\section{7. $\quad$ Findings}

The table below shows learners' responses to perceptual learning style statements (i.e., the learners' preferred senses). $50 \%$ and above indicated that the learning style was most preferred.

Table 1: Learners' Perceptual Learning Styles (in \%) $(N=110)$

\begin{tabular}{|c|c|c|c|}
\hline \multicolumn{2}{|c|}{ Elicitation Item \& Response Options } & School A (n=44) & School B (n=66) \\
\hline \multicolumn{4}{|c|}{1 I understand new work best when } \\
\hline a & presented through the lecture method with information, explanations and discussion: & 16 & 18 \\
\hline b & the information is presented through the use of visual aids: & 43 & 59 \\
\hline C & working with my hands, or making things: & 45 & 23 \\
\hline 2 & \multicolumn{3}{|l|}{ I can remember more about a lesson when } \\
\hline $\mathrm{a}$ & I listen without taking notes: & 9 & 6 \\
\hline $\mathrm{b}$ & I write things down or take notes for visual review: & 98 & 36 \\
\hline c & Tape-recorded for re-listening later: & 43 & 41 \\
\hline \multicolumn{4}{|c|}{3 I remember best by } \\
\hline a & writing things down several times, even when detailed outline is distributed & 64 & 53 \\
\hline $\mathrm{b}$ & using highlighters when reading & 23 & 26 \\
\hline $\mathrm{C}$ & setting information to rhyme, rhythm, or music to aid retention & 14 & 21 \\
\hline \multicolumn{4}{|c|}{4 I study best when } \\
\hline a & doodling while studying: & 20 & 29 \\
\hline $\mathrm{b}$ & simultaneous talking-walking takes place: & 36 & 42 \\
\hline $\mathrm{C}$ & simultaneous talking-walking, or walking-reading study takes place: & 39 & 29 \\
\hline \multicolumn{4}{|c|}{5 I learn to spell better by } \\
\hline $\mathrm{a}$ & tracing words with fingers first in order to remember them: & 77 & 53 \\
\hline \multicolumn{4}{|c|}{6 I do better in English subjects by } \\
\hline $\mathrm{a}$ & listening to lectures: & 11 & 24 \\
\hline $\mathrm{b}$ & discussing information with peers: & 48 & 33 \\
\hline$C$ & reading a textbook: & 41 & 28 \\
\hline \multicolumn{4}{|c|}{7 What helps me to concentrate? } \\
\hline $\mathrm{a}$ & Background music: & 18 & 32 \\
\hline $\mathrm{b}$ & A quiet room: & 82 & 68 \\
\hline
\end{tabular}

In table 1, it can be observed that the overall findings of all the learners included in this study, as well as their preferences in each learning style. Generally speaking, the results of this study showed that visual learning style was the most prevalent followed by the auditory learning style., tactile, kinaesthetic, musical and verbal/ linguistic respectively. The 
visual learners indicated that they understood work best when the information was presented through the use of visual aids. They remembered best when they wrote things down several times, even when detailed outline was distributed. They also indicated that they trace words with fingers first in order to remember them. When reading, they used highlighters. This result is not compatible with the result of Very few learners who indicated that they prefer to just listen, without taking notes and prefer information to be presented through the lecture method. The auditory style was the second most preferred style. The auditory style means that learners enjoy listening activities as well as listening to the teacher and their classmates. They indicated that they tape-recorded information for re-listening later: They like discussing information with peers. The tactile learners were the third most frequently indicated style. Learners enjoy working with hands and doodling. The least preferred learning style was the verbal/linguistic learning style although there were individuals in school A who indicated that they like reading books..

\section{English Language Practice}

Learners were asked to respond to statements on English language practice in Table 2. Learners were asked to tick the appropriate box after each statement.. Learners' responses are recorded in three columns.

Table 2: Learners' Responses on English Language Practice ( $\mathrm{N}=110)$

\begin{tabular}{|c|c|c|c|c|c|c|c|}
\hline \multirow{2}{*}{\multicolumn{2}{|c|}{ Questions }} & \multicolumn{2}{|c|}{ Seldom } & \multicolumn{2}{|c|}{ Sometimes } & \multicolumn{2}{|c|}{ Often } \\
\hline & & & \multirow{2}{*}{\begin{tabular}{|c|}
$A$ \\
15
\end{tabular}} & \multirow{2}{*}{$\begin{array}{c}\text { B } \\
73\end{array}$} & \multirow{2}{*}{\multicolumn{2}{|c|}{\begin{tabular}{|c|c|}
$\mathbf{A}$ & $\mathbf{B}$ \\
27 & 18 \\
\end{tabular}}} \\
\hline \multicolumn{2}{|r|}{ 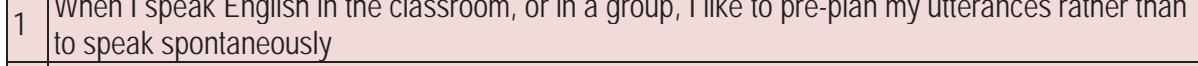 } & & 09 & & & & \\
\hline \multirow{2}{*}{\begin{tabular}{|l|}
2 \\
3 \\
\end{tabular}} & $\begin{array}{l}\text { to speak spontaneously } \\
\text { I like to speak English when I am working in a group }\end{array}$ & 36 & 29 & 48 & 47 & 16 & 24 \\
\hline & Sometimes, I feel nervous answering questions in class, because I am afraid of being wrong & 05 & 33 & 52 & 20 & 52 & 44 \\
\hline \multirow{2}{*}{\begin{tabular}{|l|}
4 \\
5 \\
\end{tabular}} & I work on my own English tasks at home, in addition to the homework assigned by my teacher & 16 & 35 & 43 & 35 & 41 & 30 \\
\hline & When I read English, I intend to understand every detail of the text & 11 & 24 & 23 & 30 & 66 & 45 \\
\hline \multirow{2}{*}{\begin{tabular}{|l|l|l}
6 \\
7
\end{tabular}} & I intend to analyse the grammatical structure of the sentence/text, when I cannot understand it. & 41 & 35 & 11 & 30 & 25 & 35 \\
\hline & When I come across a new word while listening to English, I intend to learn its pronunciation. & 18 & 21 & 30 & 47 & 52 & 32 \\
\hline 8 & I read English newspapers, magazines, or storybooks after class & 48 & 55 & 32 & 27 & 20 & 18 \\
\hline & I like to answer questions in English class & 50 & 58 & 30 & 26 & 20 & 17 \\
\hline & When my peers answer questions in class, I whisper the answer in English to myself & 16 & 48 & 57 & 35 & 27 & \\
\hline & $\begin{array}{l}\text { When my peers answer questions in class, I whisper the answer in English to myself } \\
\text { I speak English with my friends after school }\end{array}$ & 66 & 62 & 34 & 38 & 48 & 26 \\
\hline \multicolumn{2}{|r|}{\begin{tabular}{|l|l|}
12 & I take notes in English during English lessons \\
\end{tabular}} & 73 & 25 & 48 & 26 & & \\
\hline
\end{tabular}

In figure 2, it is shown that the verbal/ linguistic learning style is the least preferred learning style. The findings showed that very few learners indicated that they often pre-plan their utterances, rather than speak spontaneously, when they communicate in English in their classrooms, or groups although there are learners who indicated that they do not initiated questions, or answer questions, in the English class. The majority of learners indicated that they sometimes like to be active, and to speak English when working in a group. The study revealed that the majority of them felt nervous answering questions in class, because they were afraid of being wrong. There are learners who indicated that they often work on their own English tasks at home, in addition to the homework assigned by the teacher. They indicated that they often want to understand every detail of the text when they read, although some of them seldom intend to analyse the grammatical structure of the sentence or text, when they could not understand. They indicated that they do not read English newspapers, magazines, or storybooks, or surf internet information after class and they did not speak English with friends after school. When they came across a new word, they did not learn its pronunciation by heart first and looked it up in a dictionary afterward.

\section{Discussion of the Findings}

In table 1, the findings revealed that most learners preferred visual presentation to the textual presentation of the subject content. These learners prefer to see words written down, using pictures when describing things, writing assignments on the board, using overhead transparencies, or handouts, and writing down instructions. This confirms what Tripp and Moore(2007) found in their research on learning style identification. Auditory learners are also evident were the second preferred learning style. This finding confirms a study conducted by Aguirre, Cancino and Neira (2005) in the Adina area of Columbia. They found that the auditory learning style was dominating. When learning, auditory learners prefer various 
listening activities, such as listen and draw, listen and order pictures or a dialogue, listen and match, listen and follow a route on a map, listen and complete a form, listen and correct, listen and physically respond. The tactile learning style was the third most preferred learning style. This result is confirmed by Matthew Peacock's (2001) findings on the correlation between learning and teaching styles was that most learners favoured tactile/kinaesthetic learning styles. Zhenhui (2001) in his study found out that the most favoured style was kinaesthetic followed by visual learners. Learners in this study seemed not to prefer verbal, or linguistic learning styles. However, in contrast, the same learners, when responding to questions based on the language practice in table 2, indicated that they preferred auditory learning style. These learners prefer lectures to co-operative learning. The explanation could be that teachers encourage changes in learners' behaviour, and fostered guided style-stretching. Guided style-stretching implies that learners adapt their learning styles to suit the teachers' teaching styles.

In table 2, learners' responses revealed that linguistic learning style is the least preferred learning style. The responses to questions revealed that learners were not conscious users of meta-cognitive language learning styles, such as monitoring, planning, arranging, and self-evaluating their own learning process, nor did they have a self-study plan to improve their language skills. The researcher came to the conclusion that this was related to their learning styles which had been shaped by the way they learned English. The encouraging finding in this part of the survey is that it revealed that there were learners although very few, who intended to do some after-class reading, although the materials were scarce. The study also revealed that most of the learners want to understand every detail of the text when they read. Some do not like to analyse the grammatical structure of the sentence or text, when they could not understand. The reason for that might be the fact that they are afraid of being wrong. It is suggested that learners should realise the importance of learning English by using it continuously. However, outside class, these learners were not exposed to English reading materials. For these learners basic, meaningful, oral communication in English did not takes place. Another interesting finding in this survey is that, even though learners could realise, to some degree, the role that the strength and weakness of personality traits could play in their learning process, they did not seem to know how to effectively cope with their weaknesses, in order to enhance their strengths. This implies that the majority of learners do not prefer linguistic learning style

\section{Conclusion}

The literature reviewed, and the survey conducted, led the researcher to believe that learning styles have more influence in learning than may be realised. Preferred styles may guide the way learners learn. It was proven that learning styles may play a role in the way learners internally represent experiences, the way learners recall information, and even the words learners choose to use during English first additional language learning. The result of the analysis and the discussions indicated that there existed significant relationships between learners' learning style preferences and English proficiency level. Learners with different learning style preferences require different teaching styles from the teacher; yet, it is to the benefit of the learner to be familiar with more than one learning style, since it creates flexibility in the classroom situation. The study also revealed that each individual may possess a single style, or a combination of learning styles. According to the findings in this study, visual learning style was the most preferred learning style. The understanding of learners' learning styles by learners themselves and their teachers is very important in the learning and teaching process.

\section{Recommendations}

The researcher recommends that for learners who prefer visual learning style, teachers should provide multi-sensory resources. The resources would help learners to understand the information, for example; the learners who prefer idea generation could be engaged in group work where they would get an opportunity to brainstorm on the topic discussed. The additional language classroom should be print-rich in both schools, to cater for visual learners. Teachers should improvise; for example, use the back of old calendars as charts. They should provide and use materials, and equipment, as methods for teaching new concepts, or vocabulary. Teachers should also have reading corners in their classrooms, and provide their learners with various reading materials, such as English reading books, newspapers, etc. Teachers should also diversify their teaching styles to meet learners' needs, and classroom activity preferences. It is suggested that the earlier teachers know about the learning styles of individual learners in their English classrooms, the earlier they would be able to plan matching learners' learning styles to various teaching styles, and that would help learners to become more proficient in the English language. Teachers should combine multiple learning styles together to make lessons more vivid and interesting. Lastly, teachers need to guard against over-teaching by their own preferred learning styles. Both teachers should, sometimes, encourage changes in learner behaviour, by fostering guided style-stretching. 


\section{References}

Aguirre, L.E., Cancino, M. \& Neira, L. 2005. Dinamizacion de los procesos de ensenanza y aprendizaje de las lenguas extranjeras a partir de los estilos de aprendizaje. Retrieved June 17,2014, http:// www.tareas.wikiole.com.

Anderson, G. J. 2002. Fundamentals of educational research. Philadelphia: Routledge Falmer.

Babbie, E. 2005. The basics of social research. Belmont: Thomas Wadsworth.

Brown,H.D. 2000. Principles of language teaching and learning. $4^{\text {th }}$ ed. White Plains. New York. Longman.

Cohen, L., Manion, L. \& Morrison, K. 2000. Research Methods in Education.5th ed. London: Routledge.

Cook, V. 2000. Second language learning and language teaching. Beijing: Foreign Language Teaching and Research Press.

Department of Education.1997. Language in Education Policy. Pretoria.

Department of Education, 2002. National Curriculum Statement Grade R-9 (Schools) Policy. Overview - English. Pretoria.

Department of Education. 2011. Curriculum Assessment and Policy Statement Grade R-9 (Schools) Policy. Overview - English. Pretoria.

Ellis, R. 2010. The Study of Second Language Acquisition. Oxford University Press: China.

Edmonds, W. A. \& Kennedy, T. D. 2013. An applied reference guide to research designs: Quantitative, qualitative, and mixed methods. Thousand Oaks, CA: Sage.

Felder, R., Felder,K., \& Diet, E. J. 2002. The effects of personality type on engineering student performance and attitudes. Journal of Engineering Education, 21(1), 103-112.

Flemming, 2001

Funderstanding. 2008. Retrived on June 22, 2014 from http//www. Understanding. Com/learning-styles.com.

Gardner, H. 1983. Frames of minds: The theory of multiple intelligences. New York: Basic Books. Inc

Gibbons,P. 2002. Scaffolding learning. Portsmouth: Heinemann.

Gilbert, J. , \& Swanier, C. 2008. Learning styles: How do they fluctuate? Institute or Learning style Journal, 1, 29-40.

Guadalupe, M., Castenada,G., Juris, M.S.F. 2007. Teaching and Learning Crossroads. Zona praxima N, 8,78-93.

Hawkins, M. 2000. The reassertion of traditional authority in a constructivist pedagogy. Teaching Education, 11(3):279-296.

Kinsella,K.. 1995. Understanding and empowering diverse learners in ESL classrooms. In J.M.Reid (Ed.), Learning styles in the ESUEFL classrooms. (pp.52-61). Boston: Heinle and Heinle

Learning Theories. 2008. Cognitivism at Learning-Theories. Com. From http://www. Learning-theories. Com/ cognitivism. Html. Retrieved June, 17, 2014.

Meltzoff, A. 2000. Nurturing the young brain. How the young brain learns [Cassette recording]. Alexandria: Association for Supervision and Curriculum Development.

Peacock, M. 2001. Match or mismatch? Learning styles and teaching styles in EFL. International Journal of Applied Linguistics.11(1).20.

Shank, G. D. (2006).Qualitative research: A personal skills approach (2nded.). New Jersey: Merril Prentice Hall.

Sprenger, M. 2002. Becoming a wiz at brain-based teaching. Thousand Oaks, CA: Corwin Press.

Sprenger, M. 2003. Differentiation through learning styles and memory. Thousand Oaks, CA: Corwin Press. Styles within an elementary science methods course. Institute for Learning Styles Journa,1, 23-33.

Tripp,O.\& Moore, S 2007. Examination of pre-service teachers' learning styles and temperament

Winkler, E.G. (2007). Understanding Language. Hampshire: Ashford Colour Press.

Yin, R. K. 2009. Case study research: Design and methods, Fourth Edition. Newbury Park: CA: Sage.

Zhenhui, R. 2001. Matching teaching styles with learning styles or ESL/EFL instruction. The Internet TESL Journal, VII(7). 